\title{
Constraints Analysis in Adoption of Organic Farming by the Farmers in Krishna District of Andhra Pradesh, India
}

\author{
P. Srilatha ${ }^{1^{*}}$ and Ch. Srilatha Vani ${ }^{2}$ \\ ${ }^{1}$ KVK, Ghantasala, India \\ ${ }^{2}$ RARS, Anakapalli, India \\ *Corresponding author
}

\begin{abstract}
A B S T R A C T
India is home to 30 per cent of total organic producers in the world, but accounts only for just 2.59 per cent of the total organic cultivation area. In Krishna district mostly farmers prefer to grow paddy organically as it gives better return as compared to other crops under organic condition. Different crop growers of certified organic farmers of Krishna district of Andhra Pradesh are still facing various types of constraints in adoption of organic farming; hence the study entitled "Constraints analysis in adoption of organic farming by the farmers in Krishna district of Andhra Pradesh" was conducted in ten paddy growing villages covering 180 respondents comprising of certified organic farmers (20 from each village). With the help of a pre- tested interview schedule, a survey was conducted to collect relevant data and then appropriate statistical procedure was employed to analyse the data for assessing the effect of different constraints in the adoption component. Findings revealed that majority of the certified organic farmers faced constraints i.e. Nonavailability of traditional seeds $(75.55 \%)$ ), inadequate availability of organic inputs in time $(72.22 \%)$, lack of standard package of practices for practicing organic farming (68.33 $\%)$, lack of innovativeness $(65.55 \%)$, lack of technical guidance on organic farming $(58.89 \%)$ etc. Meaningful suggestions were encountered from the certified organic farmers for enhancing adoption of organic farming in the study area.
\end{abstract}

\section{Keywords}

Organic Farming, Agro-ecosystem

Article Info

Accepted:

24 July 2020

Available Online:

10 August 2020

\section{Introduction}

Organic production is a holistic system designed to optimize the productivity and fitness of diverse communities within the agro-ecosystem. According to (Pimentel et al, 2005) Organic farming (OF) is an agricultural production system that sustains the demands of production of healthy and safe food, with no significant dependence on chemical fertilizers, using organic matter and bio- fertilizers, cultivating with reduced tillage, environmentally safe pest management and the adoption of integrated farming systems.

The principal goal of organic production is to develop enterprises that are sustainable and harmonious with the environment. India is home to 30 per cent of the total organic producers in the world, but accounts for just 2.59 per cent (1.5 million hectares) of the total organic cultivation area of 57.8 million 
hectares, according to the World of Organic Agriculture 2018 report.

At the same time, most organic farmers are struggling due to poor policy measures, rising input costs and limited market, says a study by the Associated Chambers of Commerce and Industry of India (ASSOCHAM) and global consultancy firm Ernst \& Young. Problems are evident even in Sikkim, which was recognized as the country's first organic state in 2018. A survey by Delhi-based Centre for Science and Environment shows that the state's transition to organic farming is yet to become a true success. The survey found that the phasing out of chemicals in Sikkim was not complemented by a simultaneous increase in availability of and access to organic manure. Farmers also complained of low productivity during the transition from conventional chemical farming to organic farming. Pest attack on organic crops is another reason cited by the farmers for low productivity and demanded education and training to deal with it. Similarly, nearly 98 per cent farmers in Rajasthan are aware of ecological hazards of conventional chemicalbased farming, but fear of decline in production and unavailability of organic inputs in the market discourage them from switching to organic farming, says a 2015 study conducted by the Consumer Unity and Trust Society. According to the Indian Council of Agricultural Research, productivity on an average dips by 6.7 per cent in the first year, and the government needs to have a plan in place to support farmers during the transition. The report on Doubling of Farmers' Income by Ashok Dalwai committee, too, echoes the concern of the farmers who claim up to 30 per cent drop in yields when embracing organic. It takes about a decade to attain pre-conversion yield levels, according to the committee report. In India, still farmers face several constraints in practicing organic farming like Inadequate availability of organic inputs, scarcity of irrigation storage structures, lack of quality training on organic farming, lack of technical guidance on organic farming, Non-availability of readymade organic inputs formulation, lack of control measures for pest and disease, less number of technologies in organic farming practices (Sivaraj et al., 2017). Based on this background the present study was conducted among 180 certified organic farmers in krishna district of Andhra Pradesh.

\section{Materials and Methods}

The Krishna eastern delta region of the Krishna district is selected for this study. In this area, farmers have registered under the category of individual certified organic farmers. Farmers who are practicing organic farming in different crops like Paddy, Blackgram, Sugarcane, banana and turmeric were selected. Total 180 organic farmers were selected for the present study (Table 1). In Krishna district, three mandals (Ghantasala, Movva and Mopidevi) were selected and in each mandal 60 farmers were selected through purposive random sampling method. According to the objectives and the variables under study, a comprehensive semi structured interview schedule covering all aspects of organic farming practices was prepared. The interview schedule was prepared with the structured questions and objective type questions which were suitable to all organic farmers duly avoiding the irrelevant items. Personally contacted the selected organic farmers and interviewed with structured interview schedule. The data collected were subjected to statistical analysis to get inferences. Percentage analysis was used in descriptive analysis for making simple comparisons. Percentage was corrected to two decimal places and finally ranked constraints faced by the organic farmers (25 numbers of constraints). 


\section{Results and Discussion}

This study reveals several problems in implementing organic agriculture from the farmers' point of view, among others: lack of innovativeness, minimum government supports, less yield in initial days, chemical contamination threat from neighbor's field, less number of organic related FPOs etc. With this background, efforts were made to know the constraints experienced by organic farmers in practicing organic farming and were tested with ranking.

Seed holds endless potential for transforming our food system, especially when coupled with the principles that built the organic movement - the principles of health, ecology, and fairness. In this (Table 2), Nonavailability of traditional seeds $(75.55 \%)$ was identified as first ranked and major constraint faced by the organic farmers. organic farmers rely on seed adapted to their specific farm conditions and climates more than other farmers because they don't use synthetic pesticides and fertilizers. Seed also largely dictates the quality of our food from appearance to flavor to nutritional content. Inadequate availability of organic inputs in time $(72.22 \%)$ was identified as the second major constraint by the certified organic farmers based on the rank. Availability of quality organic inputs is critical for success of organic farming in the country. Besides rational output/input pricing, there is an urgent need to effectively meet the increasing and changing requirement of various inputs in organic agriculture. Similar results were also reported by sivaraj et al (2017). Lack of standard package of practices for practicing organic farming $(68.33 \%)$ was identified as the third major constraint by the certified organic farmers based on the rank. To grow the crops organically there is no separate standard package of practices and also validation of the methods has to be done by scientists from research stations. If package of practices are there only we can easily demonstrate in the farmer's fields and importance of the technology can be disseminated.

Data from the Table 2 revealed that the farmers/growers were very much lacked in the entrepreneurial ability for taking up any venture in a profitable manner which was followed by the lack of innovativeness $(65.55$ $\%$ ) and low responsiveness by the farmers. Similar results were also reported by Rifat Haneef et al (2019). On the other hand, farmers were quite enthusiastic to build up the entrepreneurial ability provide the scopes and opportunities of various agroentrepreneurship are properly highlighted through capacity building programmes. It was observed that, lack of technical guidance on organic farming (58.89\%) was indicated as the fifth constraint and Poor knowledge to control pest and diseases (56.11\%) was indicated as seventh constraint by the certified farmers. Farmers were very much lacking in knowledge on organic farming especially in controlling pest and diseases which leads to hindering the production and productivity of the crops. Due to this farmers were not able to grow the crops with technical knowledge. Along with technical guidance certified organic farmer's feels that lack of training on organic farming practices $(58.34 \%)$ and lack of awareness programmes on organic farming in the media $(31.66 \%)$ were also important factors which were hindering the proper farming of organic crops. So, farmers wish to increase their knowledge by undergoing trainings and awareness programmes in the media regarding organic farming. Organic agriculture has, per unit yield, a significantly lower temporal stability compared to conventional agriculture. Farmers (57.23\%) expressed that organic farming will take long period to get positive responses from the ecosystem (57.23\%). 
Table.1 Selected Mandals, Villages and respondents in Krishna district of Andhra Pradesh

\begin{tabular}{|c|c|c|c|}
\hline S.No. & Name of the Mandal & Name of Village & Number of selected farmers \\
\hline \multirow[t]{3}{*}{1} & \multirow[t]{3}{*}{ Ghantasala } & Ghantasala & 20 \\
\hline & & Ghantasala palem & 20 \\
\hline & & Srikakulam & 20 \\
\hline \multirow[t]{3}{*}{2} & \multirow[t]{3}{*}{ Movva } & Movva & 20 \\
\hline & & Kaza & 20 \\
\hline & & Gudapadu & 20 \\
\hline \multirow[t]{3}{*}{3} & \multirow[t]{3}{*}{ Mopidevi } & Mopidevi & 20 \\
\hline & & Nagaitippa & 20 \\
\hline & & $\begin{array}{l}\text { Uttara chiruol } \\
\text { lanka }\end{array}$ & 20 \\
\hline & & Total & 180 \\
\hline
\end{tabular}

Table.2 Constraints faced by certified organic farmers in adoption of organic farming Practices

\begin{tabular}{|c|c|c|c|c|}
\hline S.No. & Constraints & Frequency & Percentage & Rank \\
\hline 1 & Non-availability of traditional seeds & 136 & 75.55 & I \\
\hline 2 & Inadequate availability of organic inputs in time & 130 & 72.22 & II \\
\hline 3 & Lack of standard package of practices for practicing organic farming & 123 & 68.33 & III \\
\hline 4 & Lack of innovativeness & 118 & 65.55 & IV \\
\hline 5 & Lack of technical guidance on organic farming & 106 & 58.89 & $\mathrm{~V}$ \\
\hline 6 & $\begin{array}{l}\text { Requirement of long period to get positive responses from the } \\
\text { ecosystem }\end{array}$ & 103 & 57.23 & VI \\
\hline 7 & Poor knowledge to control pest and diseases & 101 & 56.11 & VII \\
\hline 8 & Inadequate marketing net works for organic products & 98 & 54.45 & VIII \\
\hline 9 & Insufficient premium price for organic produce & 94 & 52.22 & IX \\
\hline 10 & High cost and non- availability of labour & 91 & 50.55 & $\mathrm{X}$ \\
\hline 11 & $\begin{array}{l}\text { Complicated process and time period required for obtaining organic } \\
\text { certification }\end{array}$ & 88 & 48.89 & $\mathrm{XI}$ \\
\hline 12 & Problem in processing of the organic produces & 86 & 47.78 & XII \\
\hline 13 & Chemical contamination threat from neighbor's field & 82 & 45.56 & XIII \\
\hline 14 & Inadequate storage facility & 80 & 44.45 & XIV \\
\hline 15 & Non-availability of readymade organic inputs formulation & 78 & 43.34 & XV \\
\hline 16 & Limited experts in preparation of organic inputs & 74 & 41.12 & XVI \\
\hline 17 & Inadequate subsidies for organic cultivation of crops & 72 & 40.00 & XVII \\
\hline 18 & Lack of training on organic farming practices & 69 & 38.34 & XVIII \\
\hline 19 & High risk and uncertainty of return & 66 & 36.67 & XIX \\
\hline 20 & Lack of effective supervision and monitoring by ext. worker & 60 & 33.34 & $\mathrm{XX}$ \\
\hline 21 & Lack of awareness programmes on organic farming in the media & 57 & 31.66 & XXI \\
\hline 22 & $\begin{array}{l}\text { Less number of technologies developed by universities in organic } \\
\text { farming practices }\end{array}$ & 54 & 30.00 & XXII \\
\hline 23 & Inadequate transport facilities & 50 & 27.77 & XXIII \\
\hline 24 & Low credibility of extension worker & 49 & 27.22 & XXIV \\
\hline 25 & Less number of organic related FPOs & 45 & 25.00 & XXV \\
\hline
\end{tabular}


Thus, although organic farming promotes biodiversity and is generally more environmentally friendly, future efforts should focus on reducing its yield variability. Even though the crops were grown organically farmers were not getting premium price for their products. Especially, to sell these organic products proper marketing facilities are not present in India. In this regard, $54.45 \%$ farmers expressed that inadequate marketing net works for organic products as eighth constraint and insufficient premium price for organic produce $(52.22 \%)$ as ninth constraint. These certified organic farmers requested for separate policy for marketing of organic products. In the absence of a sound policy, we find that some traders are mixing conventional and organic food products and selling the products in the domestic market as organic at a premium price. Not only is this harmful for consumers' health, the latter are skeptical of buying organic products in the absence of regulation ensuring the authenticity of the produce. In particular, organic farming is frequently associated with claims of high labour requirements, because it needs more resources than conventional for manual and mechanical weed control, is based on a greater diversity of crops at farm level, and organic farmers more often develop marketing and processing activities on farm. Farmers expressed that High cost and non- availability of labour $(50.55 \%)$ as tenth constraint. The above explained problems are the main ten constraints experienced by the certified organic farmers while farming in Krishna district of Andhra Pradesh.

The other constraints expressed by the farmers are complicated process and time period required for obtaining organic certification (48.89\%), Problem in processing of the organic produces $(47.78 \%)$, Chemical contamination threat from neighbor's field $(45.56 \%)$, Inadequate storage facility
(44.45\%), Non-availability of readymade organic inputs formulation (43.34\%), Limited experts in preparation of organic inputs (41.12\%), Inadequate subsidies for organic cultivation of crops $(40.00 \%)$, Lack of training on organic farming practices $(38.34 \%)$, High risk and uncertainty of return $(36.67 \%)$, Lack of effective supervision and monitoring by ext. worker (33.34\%), Lack of awareness programmes on organic farming in the media (31.66\%), Less number of technologies developed by universities in organic farming practices $(30.00 \%)$, Inadequate transport facilities $(27.77 \%)$, Low credibility of extension worker (27.22\%), Less number of organic related FPOs $(25.00 \%)$. Farmers requested that process of organic certification should be an easy process so that more number of farmers can get the organic certification. And also they expressed that effective supervision and monitoring by extension workers should be there along with credibility so that they can get the proper awareness regarding new techniques in the organic cultivation. Lastly, they are requesting for more number of Farmer Producer Organizations for organically cultivated crops so that producers itself can market their products without middlemen.

In conclusion the growth of organic farming in India is relatively slower despite the fact that it is the best solution to sustain the health of soils, ecosystems and people. It relies on ecological processes, biodiversity and cycles adapted to local conditions, rather than the use of inputs with adverse effects. In India, still farmers face several constraints in practicing organic farming like availability of traditional seeds, availability of separate market for organic products, less premium price for organic products, less knowledge on control of pest and disease in organic farming, lack of standard package of practices for practicing organic farming etc. These 
constraints need to be overcome by appropriate interventions. For sustainable organic cultivation practices, standard package of practices along with extension services should be strengthened. To encourage the organic farmers, Government should frame the schemes which will be easy to market the organic products along with premium price. And also Government should aims to empower farmers through capacity development programmes in organic farm practices management, input production, quality assurance but also in value addition and direct marketing through innovative means.

\section{References}

Pimentel, D.; Hepperly, P.; Hanson, J.; Douds, D.; Seidel, R. Environmental, energetic, and economic comparisons of organic and conventional farming systems. Bio Science 2005, 55, 573-582

Rifat Haneef, Gyanendra Sharma and Taufiq Ahmad. 2019. Constraints Faced by Farmers Practicing Organic Farming in Hill Region of Uttarakhand, India. Int.J.Curr.Microbiol.App.Sci. $\quad$ 8(05): 1149-1157

The World of Organic Agriculture - Statistics and Emerging Trends 2018" published by Research Institute of Organic Agriculture (FiBL) and IFOAM Organics International

Sivaraj, P., H. Philip, M. Chinnadurai, M. Asokhan and Sathyamoorthi, K. 2017. Constraints and Suggestions of Certified Organic Farmers in Practicing Organic Farming in Western Zone of Tamil Nadu. Int.J.Curr.Microbiol.App.Sci. 6(3): 1270-1277.

\section{How to cite this article:}

Srilatha, P. and Srilatha Vani, Ch. 2020. Constraints Analysis in Adoption of Organic Farming by the Farmers in Krishna District of Andhra Pradesh, India. Int.J.Curr.Microbiol.App.Sci. 9(08): 3047-3052. doi: https://doi.org/10.20546/ijcmas.2020.908.344 